\title{
PENDEKATAN HIDROLOGI UNTUK PENILAIAN KEGIATAN PENGELOLAAN DAS
}

\author{
Oleh: Alif Noor Anna
}

\begin{abstract}
$\overline{\text { ABSTRACT }}$
The area aim in the evaluation of water resource is the river basin (DAS), because it represents a unite of energy current system, in which there are the input (i.e. rain), processor (condition of river basin $\$$ and output (overflow with its suspension). Besides, the control of process yield conecting with the ecosystem will be easy to hand-out.

The character of DAS is confirmed by the condition of physical environment, biologic, and human civilization in the area. As DAS constitutes a system in which, if there is a processor change, the output will show the difference yield. In other words it is said if there is a transition within DAS, it will be followed by the other alteration of environment.

Based on the above consideration then the current charge, as an output all together with water, sediment, and nutrient element, is usable to evaluate the DAS condition. That is why the hydrology approach is usable to evaluate the DAS management. Indicator which is usually utilized is the index of water regime, current coefficent sediment yield and chemical element including nutrient.

It had been proved with some observations carried-out by Sri Mulat Y. (1984), Sarwono (1986), M. Fachrudin (1986) and Maryono (1990). The observations pointed. out that most all of the hydrologic parameter were used in the evaluation of DAS management, only some of its were utilized but in the evaluation applied the serial data with looking at each parameter trend from year to year.

By the proof above mentioned it is concluded that hydrologic approach is usable as an evaluation methode of management operation. but this approach does not point-out the location that produced the charge together with suspension and the strongest potential of nutrient element. Besides there is no criterion standart yet, so that it's difficult to make an analysis.
\end{abstract}

\section{ABSTRAK}

Dalam evaluasi sumber daya air sasaran wilayahnya adalah daerah aliran sungai (DAS), karena pada DAS merupakan satu kesatuan sistem aliran energi, di dalamnya terdapat input, (berupa hujan), prosesor (kondisi DAS) dan output (limpasan bersama suspensinya). Disamping itu pemantauan hasil proses yang berhubungan dengan ekosistem akan lebih mudah dilakukan.

Karakter DAS ditentukan oleh kondisi lingkungan fisik, biologik dan peradaban manusia pada kawasan tersebut. Karena DAS merupakan satu sistem dimana bila ada prosesor terdapat suatu perubahan, maka akan didapatkan hasil yang berbeda pada 
sc'putnya. Dengan kata lain satu lingkungan DAS terjadi perubahan, maka segera Ekuti perubahan lingkungan yang lain.

Dengan dasar pemikiran di atas, maka debit aliran sebagai keluaran bersama air, simen dan unsur hara dapat dipakai untuk mengevaluasi kondisi DAS pada saat sersangkutan. Oleh karena itu pendekatan hidrologi dapat digunakan untuk mengevaluasi ragelolaan DAS. Indikator yang biasa dipakai adalah indeks Water Regime, koefisien ITan, sediment yield dan unsur kimia bersama unsur hara yang menyertainya.

Hal ini dibuktikan dengan beberapa penelitian yang telah dilakukan oleh peneliti IJ Mulat Y. (1984), Sarwono (1986), M.Fachrudin (1986) dan Maryono (1990). Deri peneliti tersebut ternyata tidak semua parameter hidrologi digunakan untuk nergeraluasi pengelolaan DAS, hanya beberapa yang digunakain, namun dalam ccluasinya menggunakan data seri dengan cara melihat trend (kecenderungan) nest-masing parameter dari tahun ke tahun berikutnya. Dari hasil yang didapatkan mata parameter hidrologi mempunyai kecenderungan yang menurun setelah dilakukan meriolaan DAS.

Duri bukti diatas dapat ditarik kesimpulan bahwa pendekatan hidrologi dapat Eurskan sebagai salah satu cara evaluasi pelaksanaan pengelolaan DAS. Namun mikitan ini tidak dapat menunjukkan lokasi mana yang menghasilkan debit bersama zesesi dan unsur hara yang paling potensial. Di samping itu belum ada suatu kriteria es baku guna menilai kondisi DAS, sehingga masih menyulitkan dalam analisanya.

\section{FENDAHULUAN}

Tidak dapat dielakan lagi bahwa wet saat ini kebutuhan air semakin meningkat sesuai taraf hidup manusia. tesurshan tersebut dapat digunakan mak keperluan industri, irigasi/ permaupun rumah tangga. Hal ini menujukkan bahwa Manusia sangat erpancung dari sumber air, selain number alam yang laiannya, di satu = ân di sisi yang lain ketersediaan erpocensinya relatif terbatas. Permeahan ini dapat kita lihat dari saniaknya problema tentang air yang enpal di negara kita. Misalnya, sengeunaan lahan yang sudah me- lampaui kemampuannya, terutama karena tekanan penduduk, sehingga mereka telah mengeksploitasi sumber alam (termasuk sumber air) yang berlebihan. Akibatnya terjadi bencana banjir (di musim penghujan) dan kekeringan (di musim kemarau) serta erosi dan penurunan produktivitas tanah.

Dalam evaluasi sumber daya air khususnya, secara wilayahnya adalah daerah aliran sungai (selanjutnya disingkat DAS), karena pada DAS merupakan satu kesatuan sistem aliran energi di dalamnya terdapat input (limpasan bersama suspensinya). Di samping itu pemantauan di dalam 
proses yang berhubungan dengan ekosistem akan lebih mudah.

Seperti telah dilakukan oleh Direktorat Jendral Pengairan yang mengambil langkah-langkah untuk mengelola sumber-sumber air dengan pendekatan menyeluruh terhadap satu wilayah sungai sebagai satuan wilayah pengembangan. Hal ini berarti DAS bagian hulu merupakan daerah pengendali, sedangkan bagian hilir penerima aliran tersebut dan dua-duanya merupakan satu * kesatuan (DPU, 1989:27). Maka untuk suatu DAS potensi sumber daya dapat dimanfaatkan secara optimal perlu adanya suatu pola pengembangan yang menyeluruh pada seluruh wilayah tersebut. Sehingga suatu sungai harus dalam perencanaan yang terpadu, menyangkut dari segala aspek kepentingan, mulai dari bagian hulu sampai muara sungai, karena kegiatan dibagian hulu akan memberi pengaruh pada bagian hilirnya.

Sedangkan pengertian DAS adalah suatu kalawasan yang dibatasi oleh pemisah topografik yang memberi umpan aliran dari hujan yang jatuh pada kawasan tersebut, dimana semua air yang jatuh pada DAS akan dikeringkan (dikeluarkan) melalui satu outlet tunggal. DAS merupakan satu kesatuan ekosistem yang karakternya ditentukan oleh kondisi lingkungan fisik, biologik, dan peradaban manusia pada kawasan tersebut. Oleh karena itu bila satu lingkungan terjadi pe- rubahan, maka segera diikuti perubahan lingkungan yang lain. Dengan dasar pemikiran diatas, maka debit aliran sebagai keluaran, yang bersama-sama air, sediman dan unsur hara dapat dipakai untuk mengevaluasi kondis DAS pada saat bersangkutan. Parameter hidrologi yang dapat disajikan indikasi keberhasilan pengelolaan DAS antara lain, sedimen yield, unsur kimia dan unsur hara (Suyono dan Sri Astuti Soedjoko, 1983).

\section{SISTEM DI DAS}

Sistem DAS ada masukan berupa curah hujan $(\mathrm{P})$ yang jatuh dipermukaan tanah akan mengalami berbagai peristiwa, intersepsi, infiltrasi dan perkolasi serta limpasan sebagai sisanya sekaligus outputnya. Besar kecilnya air hujan yang aliran permukaan sangat tergantung dari kondisi fisik DAS. Jika permukaan tanah tertutup oleh vegetasi, aliran permukaan menjadi kecil, karena lebih banyak air yang mendapat kesempatan untuk meresap kedalam tanah, melalui infiltrasi atau bahkan proses yang selanjutnya yaitu perkolasi. Keadaan seperti ini berarti akan mengurangi pengikisan tanah (erosi) oleh air, yang berarti sedimen yield DAS menjadi kecil pula. Sebaliknya, permukaan tanah mempunyai vegetasi yang jarang, maka air hujan akan lebih banyak yang menjadi aliran permukaan.

Aliran permukaan dipengaruhi oleh beberapa faktor yaitu topografi, iklim, 
guna lahan dan tanah. Aliran ere dari proses infiltrasi dipengaruhi - ilim, struktur dan tekstur tanah Sedangkan aliran dasar cleh struktur geologi, batuan, timbunan air fan kemiringan hidraulik tanah. Sistem air - DAS dapat dipakai sebagai - minran bahwa keluaran yang ne ilran sungai akan identik = kelabivan curah hujan yang - ack kasan DAS (sebagian Inoses), akan memberi pemang baik tidaknya kawasan makukan fungsinya sebagai rear anr

Whalnya kadar sedimen $=$ aliran sungai tergantung

CAJPAR I Siklus hidrologi di DAS (chorley: 1973) besarnya erosi yang terjadi di kawasan DAS. Kadar sedimen semakin besar, berarti erosi pada kawasan tersebutpun besar, dan sebaliknya erosi kecil, maka kadar sedimen nya kecil pula. Dalam hal ini parameter tersebut dapat dipakai sebagai petunjuk keberhasilan pengelolaan DAS. Demikian pula halnya aktivitasnya penduduk di kawasan tersebut, akan mempengaruhi kadar unsur kimia dan hara pada debit alirannya. Kegiatannya tidak menimbulkan masalah, tetapi sisanya/ limbah baik dari pertanian, industri maupun pemukiman akan mengotori tempat pembuangannya. Selanjutnya sistem DAS digambarkan pada gambar 1 dan gambar 2.

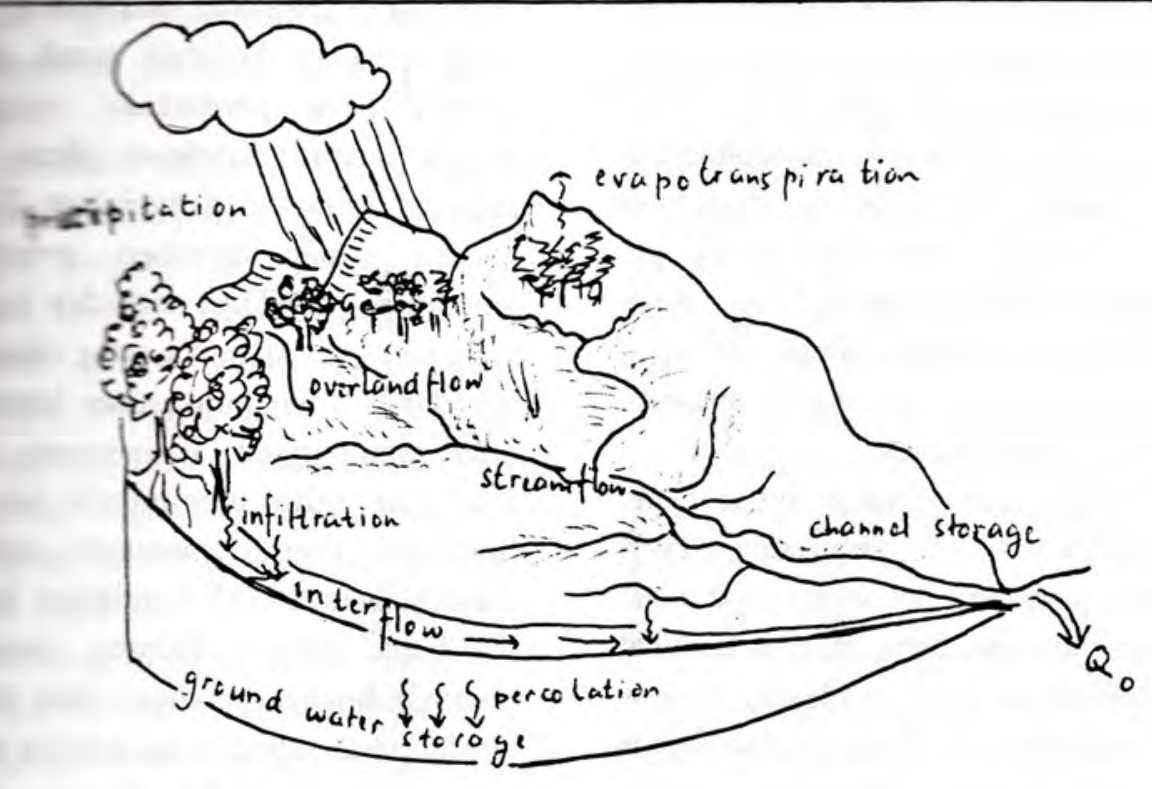

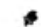




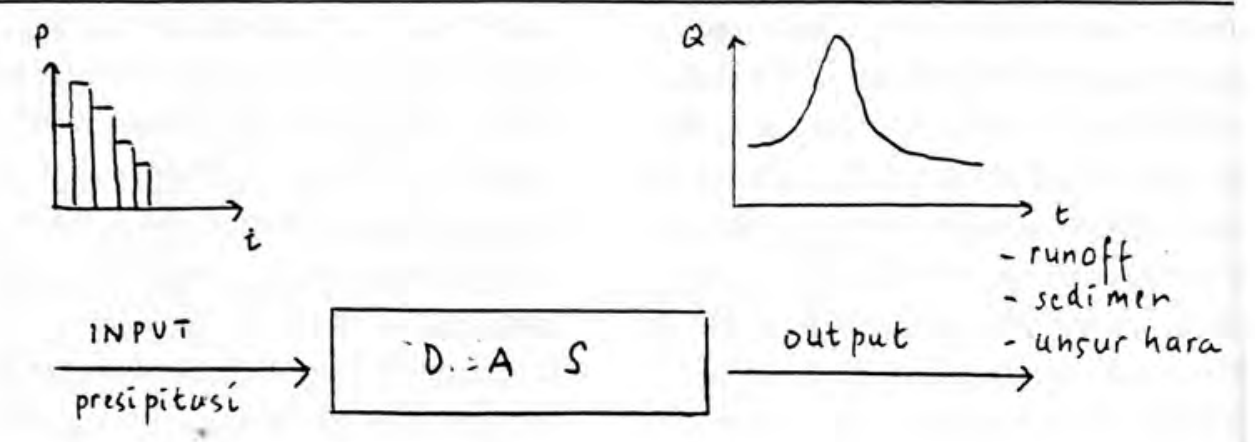

\section{PARAMETER HIDROLOGI UNTUK PENILAIAN PENGELOLAAN DAS}

Pelaksanaan pengelolaan DAS dapat berpengaruh terhadap kondisi hidrologi, artinya pengelolaan DAS yang baik, maka kondsisi hidrologinyapun baik dan sebaliknya. Parameter yang sering digunakan untuk penilaiannya adalah Indeks Water Regime (IWR), koefisien aliran, hidrograf satuan, kadar satuan, kadar suspensi dan koefisien siresesi.

IWR dapat dipakai sebagai petunjuk kisaran debit aliran sungai. IWR adalah perbandingan antara debit maksimum dengan debit minimum. Nilai perbandingan yang cenderung mengecil menyatakan bahwa kontinuitas alirannya membaik. Keadaan tersebut menunjukan bahwa debit musim penghujan tidak terlalu besar dan pada musim kemarau tidak terlalu kecil. Hal ini mengindikasikan bahwa penimbunan air di dalam DAS baik, limpasan kecil dan aliran dasar besar. Penurunan limpasan diakibatkan air yang meresap kedalam tanah atau tersimpan di permukaan (sebagai lengas tanah). Koefisien aliran dijadikan indikator pengelolaan DAS karena dapat memberi petunjuk tentang respon DAS terhadap hujan yang jatuh di dalamnya, yang selanjutnya dapat mengindikasikan kemampuan tanah untuk menyimpan air. Koefisien yang mempunyai kecenderungan (trend) menurun setelah dikelola berarti DAS kondisinya baik. Koefisien aliran dihitung dengan membandingkan air hujan yang menjadi limpasan dibagi dengan hujan total yang jatuh di DAS. Karena perhitungannya harus memasukkan wak- 
e vertentu, maka ada tiga jenis koefisien Arase yaitu :

- koefisien aliran tahunan (annual veld coeffisien).

Data aliran selama setahun dibandingkan dengan data curah hajan tahunan, dan dinyatakan dalam persen. Koefisien aliran whunan dipakai sebagai petunjuk irhilangan air di DAS.

Loefisien aliran sesaat (storm yield coeffisient).

Merupakan nisbah antara aliran banjir dengan curah hujan penye-

babnya.

koefisien laju aliran (C). Dihitung dengan rumus :

$C=$ laju aliran puncak (in/jam)

laju presipitasi rata-rata (in/jam)

Laju presipitasi rata-rata adalah amb hujan yang jatuh selama waktu umentrasi, dinyatakan dalam satuan atem.

Koefisien aliran nomor a dan b tyat dipakai sebagai petunjuk tangzean (respon) DAS terhadap curah yan sesaat. Berarti menyatakan minh persen curah hujan yang menjadi limpasan, dapat juga dipakai ríagai indikasi kemampuan permiaan tanah menyimpan dan memapkan air hujan. (Sumber: Suyono, 1084: $8 \mathrm{~s} / \mathrm{d} 11)$.

Sedangkan untuk menyatakan hulengan antara curah hujan bulanan engan debit aliran bülanan digunakan penamaan regresi dan korelasi. Di- harapkan setelah DAS dikelola gradien dari persamaan regresi akan menurun, yang membuktikan bahwa air hujan yang menjadi limpasan menjadi mengecil. Parameter hidrograf satuan merupakan cermin dari karakteristik DAS. Perubahan bentuk dari hidrograf memberikan petunjuk adanya perubahan kondisi DAS. Komparasinya dengan menggunakan pengamatan beberapa waktu (semakin banyak semakin baik). Parameter hidrograf satuan yang dinilai adalah debit puncak (peak discharge $=Q p$ ), waktu dasar aliran (time to peak $=$ TP). Sehingga pengelolaan DAS diharapkan dapat merubah nilai ke tiga parameter tersebut, yaitu QP turun, Tb lebih panjang dan memperlambat Tp-nya.

Indikator perubahan tingkat perlindungan tanah terhadap erosi adalah kadar suspensi. Debit aliran yang keluar dari outlet beserta kadar suspensinya dapat diketahui, maka jumlah muatan dalam jangka waktu tertentu dapat diketahui pula. Kecenderungan muatan suspensi yang menurun menandakan pengelolaannya semakin baik. Koefisien resesi sebenarnya bagian dari analisa hidrograf banjirnya. Komponen dari lengkung resesi berasal dari beberapa simpanan air (water storage) yaitu :
a. surface detention
b. channel storage
c. interflow
d. baseflow (groundwater storage). 
Oleh karena itu semakin besar koefisiennya akan mengindikasikan bahwa dalam DAS tersebut telah banyak tersimpan air. Berarti pengaruh dari pengelolaan DAS mempunyai dampak positif.

\section{BEBERAPA PENELITIAN \\ PENGELOLAAN DAS \\ DENGAN \\ PENDEKATAN HIDROLOGI}

Sarwono (1986), M. Fachrudin (1986) dan Maryono (1990), agar dapat memberi gambaran seberapa kuatnya pendekatan ini untuk evaluasi pengelolaan DAS. Karena masih ada pendekatan-pendekatan yang lain (dari disiplin ilmu lain) yang tentunya mempunyai argumentasi sendiri sesuai dengan pengetahuan dan pengalaman yang pernah dilakukannya. Walaupun pada dasarnya sama yaitu ingin menilai tentang pengelolaan DAS, yang

Tabel 1.ParameterHidrologiyang Digunakan untuk Evaluasi Pengelolaan DAS dari Setiap Peneliti.

\begin{tabular}{lllllll}
\hline Nama & DAS & \multicolumn{9}{l}{ Parameter Hidrologi } \\
\cline { 3 - 7 } Peneliti & & C & IWR & HS & Qs & $\begin{array}{l}\text { Reg- } \\
\text { Kor }\end{array}$ \\
\hline Sri Mulat Y. & Cimanuk & $*$ & - & - & $*$ & $*$ \\
Sarwono & Samin & $*$ & $*$ & $*$ & - & $*$ \\
M. Fachrudin & Keduang & $*$ & $*$ & $*$ & $*$ & $*$ \\
Maryono & bengawan Solo & $*$ & $*$ & $*$ & $*$ & $*$ \\
& Hulu & & & & & \\
\hline
\end{tabular}

Sumber:

Sri Mulat Y. (1984), Sarwono (1986), M. Fachrudin (1986) dan Maryono (1990).

Keterangan:

$+$

C

$=$ diatas Leuwigoong

IWR

$=$ Koefisien aliran sesaat dan tahunan

QS

= Indeks Water Regime

Reg-Kor

$=$ Debit suspensi

HS Analisa hidrografi satuan observasi

Evaluasi pengaruh pengelolaan DAS dengan pendekatan hidrologi pada sub bab ini mencoba membahas beberapa hasil penelitian yang telah dilakukan oleh Sri Mulat Y.(1984), bertujuan pengendalian erosi, pengawetan sumber daya alam, peningkatan produksi pertanian dan peran masyarakat terhadap program penyelamatan hutan, tanah dan air. 


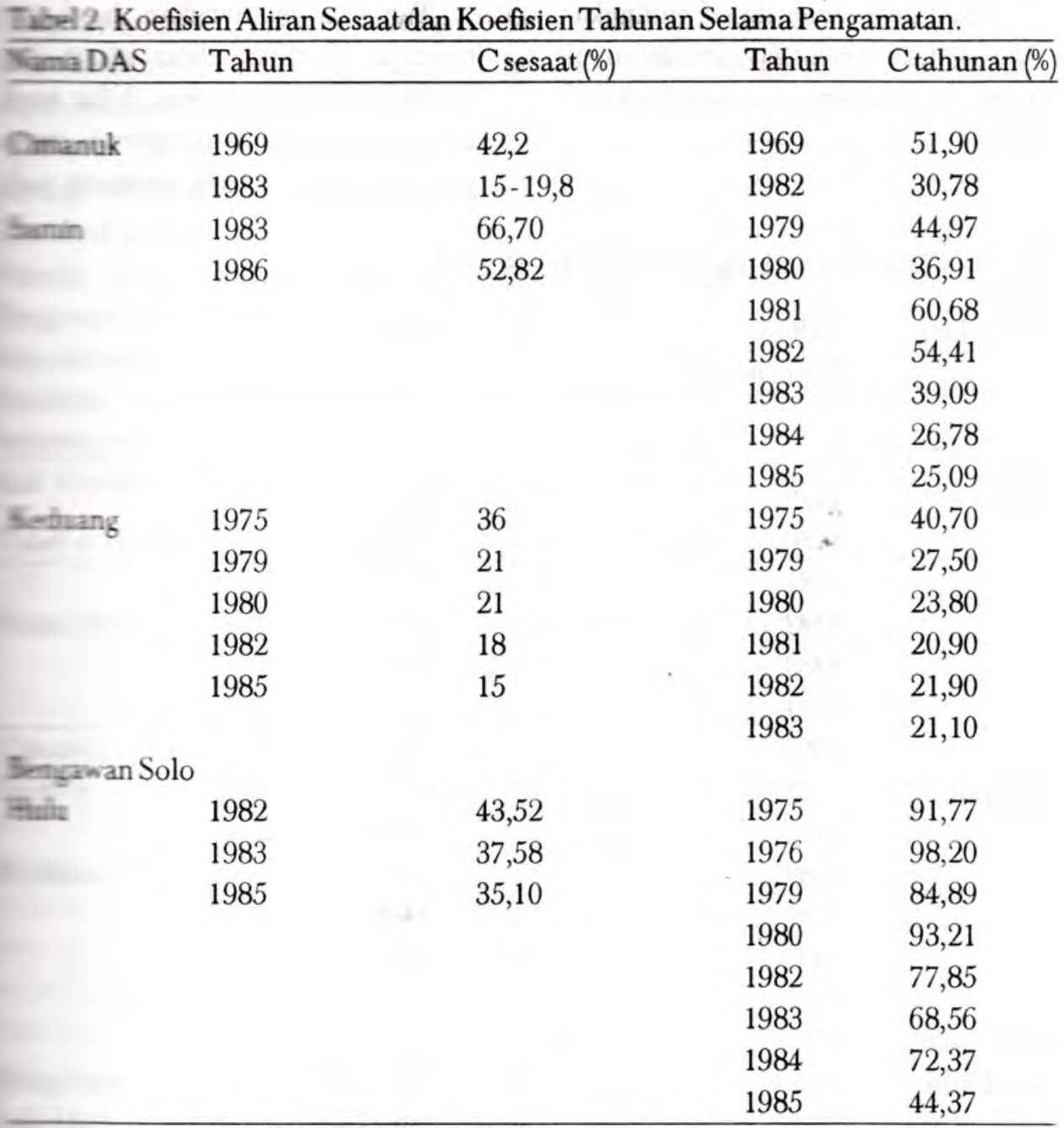

Sumber: Sri Mulat Y. (1984), Sarwono (1986),

M. Fachrudin (1986) dan Maryono

Tabel 1. memperlihatkan parameerer hidrologi yang digunakan untuk nulrasi pengelolaan DAS di maans-masing daerah penelitiannya. Termiata tidak semua parameter hidrologi cang telah disebut pada sub bab eriahulu digunakan untuk menganathat hal ini tergantung dari data sekunser yang tersedia, sebab kemungkinan sangat kecil mengadakan pengukuran sendiri. Untuk keperluan anlisisnya memerlukan data seri dengan periode tertentu yang tentunya memerlukan waktu yang panjang pula. Di samping itu belum ada aturan baku yang menyatakan syarat minimal parameter yang digunakan untuk keperluan evaluasi pengelolaan DAS. 
Selanjutnya akan diperbandingkan data dari ke empat (4) peneliti untuk mendapatkan simpulan yang seharusnya.
Tabel 2. menyajikan hasil perhitungan koefisien aliran sesaat, dan koefisien aliran tahunan. Nilai koefisien aliran sesaat umumnya memperlihatkan trend yang menurun pada

Tabel 3. IWR Selama Pengamatan pada DAS Observasi

\begin{tabular}{lll}
\hline Nama Das & $\begin{array}{l}\text { Tahun } \\
\text { Pengamatan }\end{array}$ & IWR \\
\hline \multirow{3}{*}{ Cimanuk } & & \\
Samin & 1979 & $16,9: 1$ \\
& 1980 & $13,07: 1$ \\
& 1981 & $12,7: 1$ \\
& 1982 & $11,1: 1$ \\
& 1983 & $13,55: 1$ \\
& 1984 & $12,66: 1$ \\
Keduang & 1985 & $41,28: 1$ \\
& 1975 & $6,6: 1$ \\
& 1979 & 103,8 \\
& 1980 & $1433,7: 1$ \\
& 1981 & $44802,5: 1$ \\
& 1982 & $18973,3: 1$ \\
Bengawan & 1975 & $3,97: 1$ \\
Solo Hulu & 1976 & $25: 1$ \\
& 1979 & $35: 1$ \\
& 1980 & $208: 1$ \\
& 1982 & $131: 1$ \\
& 1983 & Tak dapat dihitung, \\
& 1984 & karena Qmin $=0$ \\
& 1985 & $374: 1$ \\
& & $67: 1$ \\
& & Tak dapat dihitung \\
& & karena Qmin =0 \\
& &
\end{tabular}

Sumber: Sri Mulat Y. (1984), Sarwono (1986), M. Fachrudin (1986) dan Maryono (1990). 
setiap pengamatan, hanya saja dari DAS Cimanuk dan DAS Samin kurang dapat memperlihatkan trend karena pe ngamatan (2) dua tahun, sehingga kurang representatif untuk dapat Akatakan semakin menurun trendnya. Kamun DAS Keduang dan DAS Bengawan Solo Hulu memperlihatkan kecenderungan menurun, dengan ḋemikian adanya pengelolaan DAS berpengaruh positif. Sedangkan trend an koefisien aliran tahunan kurang
Hasil perhitungan IWR disajikan pada tabel 3. Dari nilai yang didapatkan ternyata memperlihatkan trend yang tidak beraturan. Walaupun menurut kriteria DAS masih dapat dikatakan ideal, karena mempunyai nilai kurang dari 50:1, kecuali di DAS Keduang pada tahun 1980, 1981 dan 1982 serta DAS Bengawan Solo Hulu tahun 1979 yang melebihi ambang kritis 200:1 (Sehat Noryadi dalam Sarwono, 1986:71). Dalam hal ini

Tabel 4. Nilai ParameterHidrograf Satuan selama Pengamatan

\begin{tabular}{|c|c|c|c|c|}
\hline \multirow[t]{2}{*}{ Xama DAS } & \multirow[t]{2}{*}{ Tahun } & \multicolumn{3}{|c|}{ Parameter Hidrograf Satuan } \\
\hline & & $\begin{array}{c}\overline{\mathrm{Qp}} \\
\text { (m3/det) }\end{array}$ & $\begin{array}{c}\mathrm{Tp} \\
(\mathrm{jam})\end{array}$ & $\begin{array}{c}\mathrm{Tb} \\
(\mathrm{jam})\end{array}$ \\
\hline Ormanuk & - & - & - & - \\
\hline \multirow[t]{2}{*}{ Samin } & 1983 & 15,72 & 2 & 21 \\
\hline & 1986 & 12,03 & 4 & 18 \\
\hline \multirow[t]{5}{*}{ Fieduang } & 1975 & 23,21 & 3 & 12 \\
\hline & 1979 & 19,12 & 2 & 14 \\
\hline & 1980 & 12,92 & 2 & 21,15 \\
\hline & 1982 & 11,37 & 3 & 17 \\
\hline & 1985 & 14,28 & 2 & 18 \\
\hline B-ngawan & 1982 & 30,14 & 2 & 9 \\
\hline \multirow[t]{2}{*}{ Silb Hulu } & 1983 & 18,84 & 2 & 10,5 \\
\hline & 1985 & 15,96 & 3 & 11 \\
\hline
\end{tabular}

Sumber: Sri Mulat Y. (1984), Sarwono (1986),

M.Fachrudin (1990) dan Maryono (1990).

enter, walaupun diakhir tahun pengamatan semakin menurun seperti ans diharapkan. Inipun dapat dikataen berpengaruh positif, walaupun ane diterangkan lebih lanjut tentang imakikteraturan tren̊d nya. tentunya harus dikaji secara mendalam, karena yang dilihat hanya kisaran debit maksimum dan debit minimumnya, misalnya dari variasi hujan yang jatuh dalam DAS tersebut. 
Tabel 5. BesarDebit Suspensi selama Pengamatan

\begin{tabular}{llc}
\hline Nama DAS & Tahun & Debitsuspensi(ton/tahun) \\
\hline \multirow{2}{*}{ Cimanuk } & & \\
Samin & - & - \\
Keduang & 1981 & - \\
& 1983 & 354.275 \\
& 1984 & 410.589 \\
& 1985 & 344.813 \\
Bengawan Solo & & \\
Hulu & 1981 & $1.968 .461,9$ \\
& 1982 & $676.437,7$ \\
& 1983 & $592.624,3$ \\
& 1984 & $55.720,8$ \\
& 1985 & $475.136,8$ \\
\hline
\end{tabular}

Sumber: Sri Mulat Y.(1984), Sarwono (1986), M.Fachrudin (1986) dan Maryono (1990).

Tabel 4. yang memperlihatkan ukuran (selanjutnya menentukan bentuk) hidrograf satuan, menunjukkan kecenderungan bentuk hidrograf satuan yang membaik, yaitu Qp turun, memperlambat $\mathrm{Tp}$ dan $\mathrm{Tb}$ lebih panjang. Hal ini mengindikasikan bahwa pengelolaan DAS mempunyai pengaruh positif.

Besarnya debit suspensi yang disajikan pada tabel 5. dari empat (4) DAS yang diteliti, hanya dua (2) yang menggunakan sebagai salah satu tolok ukur tentang pengelolaan DAS. Umumnya selama pengamatan baik pada DAS Keduang maupun DAS Bengawan Solo Hulu memperlihatkan kecenderungan semakin menurun, walau pada tahun 1984 di DAS Bengawan Solo Hulu debit suspensi naik cukup besar dibandingkan tahun 1983 dan 1982. Hal ini dikatakan oleh Maryono (1990), karena kenaikan debit yang terjadi pada tahun yang sama dan debit suspensi akan tergantung dari debit aliran yang dalam pembuatannya menggunakan persamaan SuspendedSedimen Ruting Curve. Selain itu kenaikan debit ternyata tidak disebabkan hujan yang tinggi, dengan demikian ada faktor lain yang menyebabkan kenaikan debit aliran nya. Pada parameter ini ternyata berpengaruh positif terhadap kegiatan pengelolaan DAS.

Berdasarkan lampiran 1 dan lampiran 2, memperkuat pula tentang anali- 
sis regresi-korelasi mempunyai kecenderungan gradien yang semakin kecil. Oleh karena kegiatan pengelolaan DAS berpengaruh positif pula dengan analisis regresi-korelasi. Dalam hal ini hasil penelitian dari Sri Mulat Y. tidak dilampirkan karena periode pengamatan untuk analisis ini hanya dua (2) tahun, sehingga kurang representatif.

\section{$\overline{\text { KESIMPULAN }}$}

DAS merupakan suatu sistem dimana komponen-komponen penyusun sistem tersebut adalah hujan sebagai input, struktur sistemnya kondisi DAS, sedang outputnya berupa aliran sungai beserta sedimen dan unsur hara. Di dalam pendekatan sistem lebih mementingkan konversi input kedalam outputnya. Oleh karenanya dalam evaluasi tindakan pengelolaan DAS dapat didekati dengan parameter hidrologi. Yaitu menghitung besarnya fenomena keluaran dari waktu ke waktu, yang selanjutnya dianalisis melalui trendnya (kecenderungannya).

Parameter hidrologi yang dapat digunakan untuk evaluasi pengelolaan DAS antara lain : Indeks Water Regime, koefisien aliran, analisis hidrograf satuan, debit suspensi dan regresi-korelasi antara hujan dan aliran. Untuk mengetahui kecenderungannya, makâ harus menggunakan data seri. Pengamatan dengan periode tahun yang panjang akan menghasilkan kecenderungan yang mendekati keadaan yang sebenarnya Oleh karenanya perlu memperhatikan kualitas data sekunder yang digunakan, disamping data tentang kegiatan pengelolaannya sendiri seperti jenis, lokasi dan jumlahnya. Agar dapat memberikan argumentasi yang kuat, bila didapatkan kecenderüngan yang melenceng dari konsep dasarnya.

Evaluasi dengan pendekatan hidrologi ini masih terdapat beberapa kelemahan yang perlu dikaji lebih dalam lagi, seperti tidak diketahuinya lokasi yang pasti wilayah penghasil output yang potensial. Potensial dalam hal erosinya (dalam hal ini penghasil suspensi), debit banjir maupun wilayah penangkap hujan-hujan yang terbanyak. Di samping itu semua parameter tersebut pemakaiannya selalu menggunakan rerata, yang dalam hal ini tentunya tidak menggambarkan kondisi yang sebenarnya, seperti yang dilakukan pada analisis hidrograf satuan dimana hujan dan banjir (debit) menggunakan data yang dirataratakan, demikian juga dalam analisis IWR nya. Selain itu pendekatan hidrologi belum ada kriteria yang baku untuk mengevaluasi upaya pengelolaannya, sehingga sering menyulitkan dalam analisanya. 


\section{DAFTAR PUSTAKA}

Alif Noor Anna. 1993. Pengelolaan dan Pelestarian Sumber Daya Air : Tinjauan Hidrologi pada DAS. Akademika, No,1 tahun XI 1993. Surakarta : Muhamadiyah University Press.

Chorley, RJ 1973, Introduction to hydrology. Suffolk: Methuen \& Co Lid.

Maryono, 1990 Penilaian Kondisi Limpasan dalam kaitannya dengan Pengelolaan

Daerah Aliran Sungai Bengawan Solo Hulu, Kabupaten Wonogiri Jawa Tengah. Skripsi. Surakarta: Fakultas Geografi UMS.

M. Fachrudin ,1986. Pengaruh Pengelolaan Daerah Aliran Sungai terhadap Limpasan dan Debit Suspensi di DAS Keduang Wonogiri. Skripsi. Yogyakarta: Fakultas Geografi UGM.

Sarwono, 1986. Penilaian Karakteristik Aliran Sungai dalam kaitannya dengan Pengelolaan Aliran Sungai da DAS Samin Surakarta. Skripsi. Yogyakarta: Fakultas Geografi UGM.

Suyono dan Sri Astuti Soedjoko, 1983. Konsepsi Metoda Evaluasi Pengawetan Tanah dan Air dengan pendekatan Hidrologi. Sarasehan I di Wanagama I. Yogyakarta: Fakultas Geografi UGM.

Sri Mulat Y. 1984. Penilaian Kondisi Limpasan dalam kaitannya dengan Pengelolaan Daerah Aliran Sungai di DAS Cimanuk di atas Leuwigoong, Kabupaten Garut Jawa Barat. Skripsi. Yogyakarta: Fakultas Geografi UGM.

Van de Griend, H.A 1979. Modelling Catchment Response and Runoff Analysis. Amsterdam: Institute of Eart Science - Free University. 


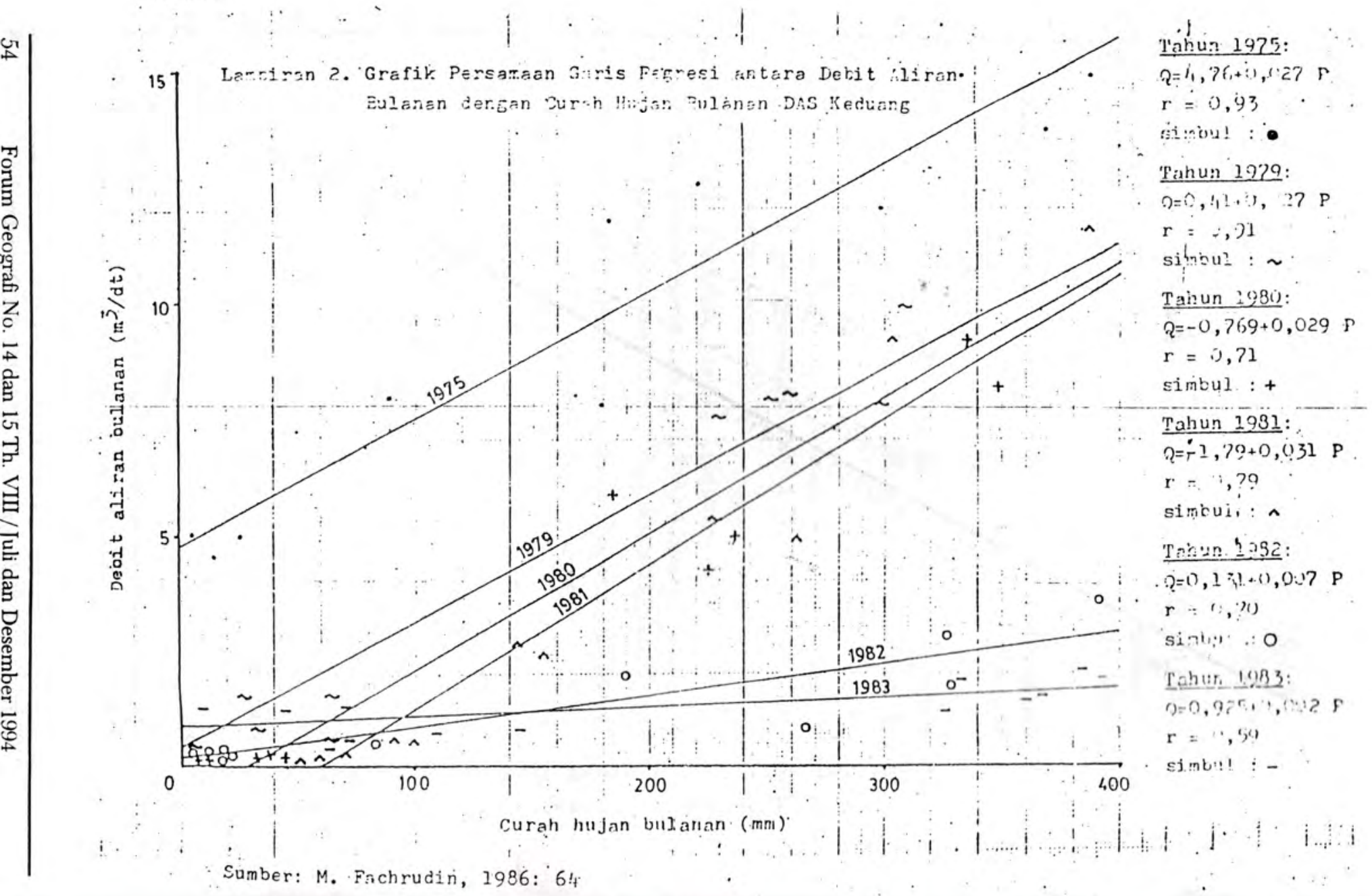

